\title{
Ovarian involvement of a desmoplastic small round cell tumor of unknown primary origin with lymph node and lung metastases: A case report
}

\author{
YU-PING XIE ${ }^{1}$ and YANG-MEI SHEN ${ }^{2}$ \\ ${ }^{1}$ Department of Oncology, Chengdu First People's Hospital, Chengdu, Sichuan 610061; ${ }^{2}$ Department of Pathology, \\ West China Second University Hospital, Sichuan University, Chengdu, Sichuan 610041, P.R. China
}

Received August 28, 2014; Accepted September 9, 2015

DOI: $10.3892 / \mathrm{ol} .2015 .4012$

\begin{abstract}
Desmoplastic small round cell tumors (DSRCTs) were initially characterized as exhibiting divergent differentiation and were extremely aggressive, belonging to the family of 'small round blue cell tumors'. Due to a male predominance, to date, only 15 cases in women have been reported in the English literature. The present study describes a case of DSRCT in a young woman who initially presented with ovarian masses accompanied with lymph node and lung metastases. A correct diagnosis was reached by combining the hematoxylin and eosin, and immunohistochemical staining results. Following surgery, the patient underwent the chemotherapy and, 3 months later, is in a good condition. The study also provides an overview of this uncommon disease.
\end{abstract}

\section{Introduction}

Desmoplastic small round cell tumor (DSRCT) was originally described and reported in a study by Gerald and Rosai in 1989 (1). DSCRT is very uncommon and only 15 cases in the English literature were reported until now (2-10). The DSRCT primarily affects children and young adults, particularly young men, with a reported male to female ratio of 4:1 (11). The initial presenting symptoms are associated with the tumor involvement, such as pain and abdominal distention, however, the majority of the patients present with widespread intra-abdominal and pelvic involvement when first examined. The mass was characterized as exhibiting divergent differentiation and was an extremely aggressive tumor belonging to the family of 'small round blue cell tumors' (12-15). Despite the aggressive nature of DSRCT,

Correspondence to: Professor Yang-Mei Shen, Department of Pathology, West China Second University Hospital, Sichuan University, 20 Renmin South Road 3rd Section, Chengdu, Sichuan 610041, P.R. China

E-mail: sym.julia@163.com

Key words: immunohistochemistry, desmoplastic small round cell tumor, ovary it has low overall survival rates; the overall progression-free 5 -year survival rate of patients is $18 \%(2,16)$. Since there are no symptoms at the early stage it is very difficult to make correct diagnosis at the early stage. The present study describes a case of DSRCT in a young woman who initially presented with ovarian masses accompanied with lymph node and lung metastases.

\section{Case report}

Clinical manifestation. On November 11, 2013, a 30-year-old female (gravida 3, para 1) initially presented to West China Second University Hospital (Chengdu, China) with abdominal fullness. Pelvic examination revealed bilateral adnexal masses. The patient's past medical history was unremarkable. Transabdominal and transvaginal ultrasonography showed the adnexal masses were irregular, complex and predominantly solid, but partially cystic. Chest, abdominal and pelvic computed tomography (CT) scans demonstrated multiple, bilateral intrapulmonary nodules, bilateral ovarian masses and pleural involvement. The level of the tumor marker serum carbohydrate antigen-125 (normal, <35 U/ml) was slightly increased at $50.8 \mathrm{U} / \mathrm{ml}$.

Treatment. The patient underwent an exploratory laparotomy. Intraoperatively, large, irregular, bilateral ovarian masses accompanying metastatic nodules that varied in size adhering to the diaphragm, peritoneum, omentum, stomach surface and uterine surface were observed. Analysis of the frozen sections revealed that the tumor was composed of small and round tumor cells growing in cluster and separated by desmoplastic stromal cells. The mitotic count of the tumor cells was high ( $\leq 15$ per 10 high power fields). Thus, the tumor was diagnosed as a poorly-differentiated carcinoma. A right salpingooophorectomy and partial omentectomy were performed. The patient was still undergoing chemotherapy on February 5, 2014 (intravenous administration of $2 \mathrm{mg}$ vincristine, $50 \mathrm{mg} / \mathrm{m}^{2}$ doxorubicin and $500 \mathrm{mg} / \mathrm{m}^{2}$ cyclophosphamide on day 1 , repeated every 3 weeks) at 3 months after the initial presentation, and the follow-up showed a partial response, with a decreased tumor nodule size and no evidence of further metastasis. The patient refused further treatment and follow-up. 
Pathological characteristics. Macroscopically, the right ovarian mass exhibited a smooth surface and measured $6.5 \times 4.0 \times 3.0 \mathrm{~cm}$ (Fig. 1). The cut surface was yellowish, lobulated and predominantly solid, with partially mucoid cystic areas and necrosis. The omental implant nodules were firm and tan-white, with greatest diameters ranging from 0.5 to $2.5 \mathrm{~cm}$. Microscopically, the tumor was characterized predominantly by nests or/and clusters of small, round to oval-shaped cells separated by a desmoplastic stroma (Fig. 2). The tumor and stromal cells were distinctive: The aggressive tumor cells exhibited hyperchromatic nuclei, inconspicuous nucleoli and scant cytoplasm, while the desmoplastic stroma was composed of elongated spindled cells with fibroblastic features. The mitotic count was estimated up to 15 mitotic figures per 10 high-power fields. Immunohistochemical staining was performed using the antigen retrieval method. The small round cells were positive for vimentin, broad-spectrum cytokeratins (AE1/AE3), CAM5.2, epithelial membrane antigen (EMA) and desmin, with a dot-like staining pattern (Fig. 3), but were negative for inhibin, calretinin, cluster of differentiation (CD)99, neuron-specific enolase (NSE), synaptophysin, Melan-A and HMB45, among others. The overall immunohistochemical staining findings in the small round cells are summarized in Table I. Based on the morphology and immunohistochemistry findings, a final diagnosis of ovarian involvement of a DSRCT was made.

\section{Discussion}

DSRCT was first reported in 1989 as a rare tumor of uncertain histogenesis arising in the pelvis or scrotum in young men $(1,12)$. Since then, further cases have been described and reported. This rare, extremely aggressive tumor usually affects individuals at adolescence and in early adulthood, with a mean age of 25 years $(1,17-19)$. The patient in the present study was slightly older than this mean at 31 years old. Only 15 cases previously reported in women in the English literature (3). A summary of the 15 cases is presented in Table II (2-10). Compared with the present case with the reported cases in Table II, the majority of the characteristics of the present case were similar to the others, including the locations, which were unilateral or bilateral ovarian involved and presented as solid and/or cystic. All the patients underwent surgical debulking and chemotherapy. The majority of patients demonstrated partial remission, however, all the patients succumbed to the disease 4-40 months following treatment due to recurrence and metastases.

The majority of patients are characterized with extensive peritoneal spread at the time of diagnosis, while the initial presenting symptoms, such as pain, abdominal distension, palpable mass and ascites, are associated with the tumor involvement. In the majority of the reported cases $(2,4-8)$, the clinical presentation of ovarian DSRCT as a bilateral large ovarian mass accompanied with widespread nodule implants throughout the peritoneum, with ascites, is observed upon exploratory laparotomy. The most common sites of metastasis are the liver, lymph nodes, lungs and bone marrow (20). In the present case, the initial symptom upon presentation was abdominal fullness, however, bilateral intrapulmonary nodules and metastatic deposits were found pre- and post-surgery.

It is difficult to correctly and rapidly form a pathological diagnosis of DSRCT based on the initial histological
Table I. Expression of immunolabelings in the small round cells.

\begin{tabular}{lc}
\hline Immunolabeling & Expression \\
\hline CAM5.2 & $\mathrm{P}$ \\
Pan-CK & $\mathrm{P}$ \\
EMA & $\mathrm{P}$ \\
VIM & $\mathrm{P}$ \\
Des & $\mathrm{P}$ (dot-like staining pattern) \\
Ki-67 & $\mathrm{P}(\sim 70 \%)$ \\
Inhibin & $\mathrm{N}$ \\
CD99 & $\mathrm{N}$ \\
NSE & $\mathrm{N}$ \\
Syn & $\mathrm{N}$ \\
HMB45 & $\mathrm{N}$ \\
S100 & $\mathrm{N}$ \\
\hline
\end{tabular}

P, positive; N, negative; CK, cytokeratin; EMA, epithelial membrane antigen; VIM, vimentin; Des, desmin; CD, cluster of differentiation; NSE, neuron-specific enolase; Syn, synaptophysin; HMB, human melanoma black.

examination of the specimen due to the tumor cells exhibiting divergent differentiation. As aforementioned, DSRCTs belong to the family of 'small round blue cell tumors', which consist of several tumor types, including extraskeletal Ewing's sarcoma/primitive neuroectodermal tumors, rhabdomyosarcoma and lymphoma. All the tumors have similar features. If the microscopic findings of a young female show small, round and blue tumor cells, a common ovarian tumor may first be highly suspected, such as a germ cell tumor, a sex cord stromal tumor and Krukenberg's tumor. Therefore, to make a correct diagnosis, a combination of immunohistochemical staining and cytogenetic analysis can be useful and important. The coexpression of cytokeratins, EMA, vimentin, desmin and NSE is a unique immunophenotype of DSCRTs $(3,4)$. By contrast, negative immunohistochemical stains for Myogenin, MyoD1, chromogranin, HMB45 and CD45 can assist in distinguishing DSRCT from the aforementioned tumors. In the present case, a sex cord tumor or a germ cell tumor were suspected at first, as the patient was a young female. However, none of the immunophenotype markers for these tumors were expressed. Next, a possible diagnosis of a small round blue cell tumor was suggested and the corresponding panel of markers was applied. The tumor cells exhibited coexpression of the following markers: Epithelial staining for cytokeratins and EMA, mesenchymal staining for vimentin and muscle staining for desmin, which is characterized by a dot-like staining pattern, but no expression of the rhabdomyosarcoma markers myogenin and MyoD1. All the findings fulfilled the criteria for a DSRCT.

The optimal therapy for DSRCT patients has not yet been determined yet due to the rarity of the disease, and the small number of patients and multi-institutional clinical trials for the tumor. It is important and useful for the attending physician to seek the best therapy based on the individual responses and clinical courses of the previously reported DSRCT patients who were treated using various regimens. Although the 


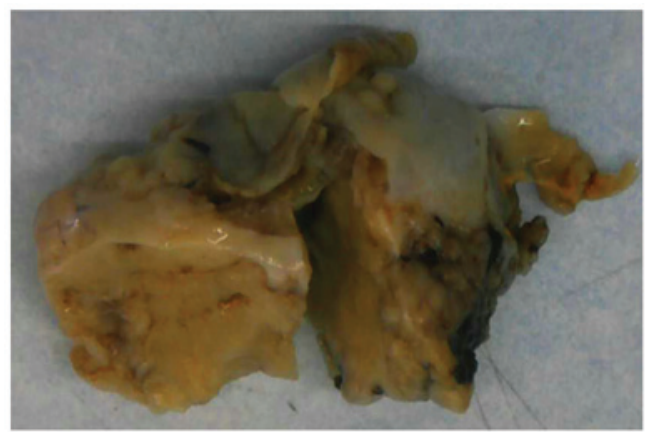

Figure 1. Macroscopically, the cut surface of the right ovarian mass was yellowish and lobulated, and predominantly solid.

A

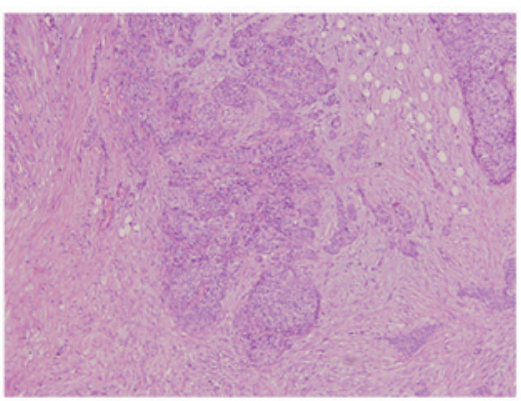

C

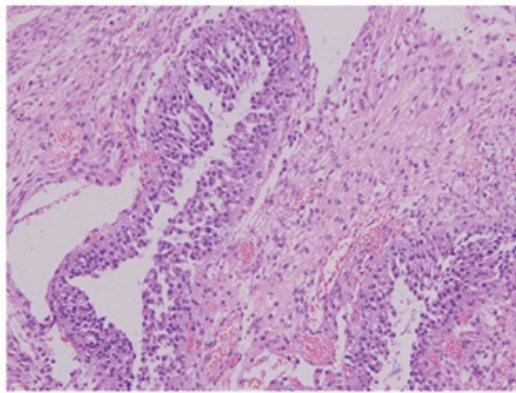

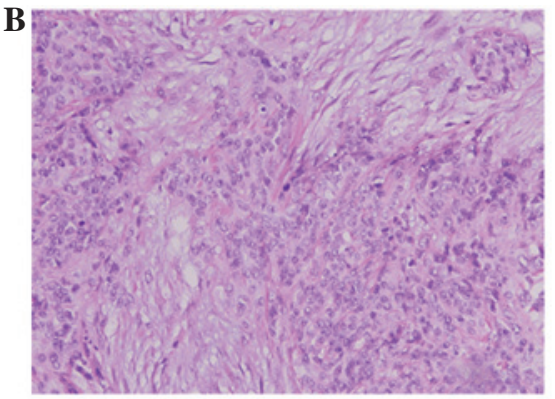

D

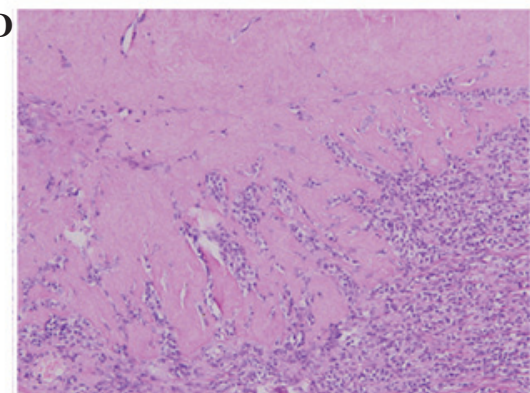

Figure 2. Microscopically, (A) the tumor was characterized predominantly by nests, clusters of small round to oval-shaped cells separated by a desmoplastic stroma (magnification, x200). (B) The mitotic count was estimated to be 15/10 high-powered field. (C and D) The cystic follicle and corpus albicans of the ovary were infiltrated by the tumor cells. (hematoxylin and eosin staining; magnification, $\mathrm{x} 400$ ).

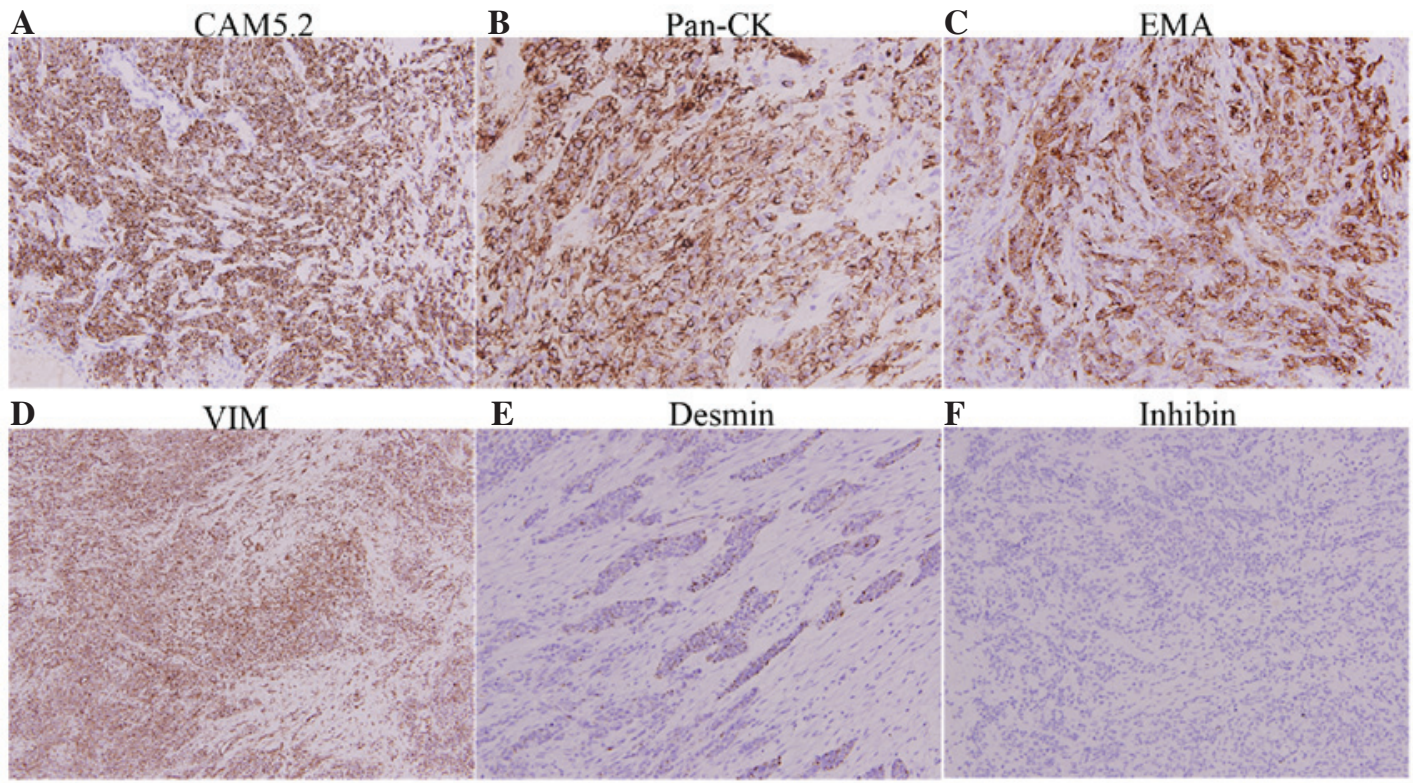

Figure 3. Immunohistochemical staining. The tumor cells were positive for (A) CAM5.2, (B) pan-cytokeratin (Pan-CK), (C) epithelial membrane antigen (EMA), (D) vimentin (VIM) and (E) desmin, with a dot-like staining pattern, but were negative for (F) inhibin (Envision; magnification, $\mathrm{x} 400$ ). 
Table II. Summary of the 15 reported cases of ovarian DSRCT. Modified from Ota et al (4) and Nakayama et al (3).

\begin{tabular}{|c|c|c|c|c|c|c|}
\hline Case, $\mathrm{n}$ & Reference & $\begin{array}{l}\text { Age, } \\
\text { years }\end{array}$ & $\begin{array}{c}\text { Ovarian } \\
\text { involvement }\end{array}$ & $\begin{array}{l}\text { CA-125, } \\
\mathrm{U} / \mathrm{ml}\end{array}$ & Initial treatment & Follow-up \\
\hline 1 & Young et al (5) & 15 & $\begin{array}{l}\text { Unknown laterality: } \\
9 \text { and } 8.5 \mathrm{~cm} \\
\text { (solid) }\end{array}$ & Not done & $\begin{array}{l}\text { Surgical debulking } \\
\text { with multi-agent } \\
\text { chemotherapy } \\
\text { including carboplatin }\end{array}$ & $\begin{array}{l}\text { Succumbed at } \\
4 \text { months }\end{array}$ \\
\hline 2 & Young et al (5) & 15 & $\begin{array}{l}\text { Right: } 15 \mathrm{~cm} \\
\text { (solid/cystic) } \\
\text { Left: } 9 \mathrm{~cm} \text { (solid) }\end{array}$ & Not done & $\begin{array}{l}\text { Surgical debulking, } \\
\text { no chemotherapy }\end{array}$ & $\begin{array}{l}\text { Secondary } \\
\text { debulking at } \\
7 \text { months }\end{array}$ \\
\hline 3 & Young et al (5) & 14 & Right: 5.3 cm (solid) & Not done & Surgical debulking & None \\
\hline 4 & Zaloudek et al (2) & 22 & $\begin{array}{l}\text { Right: } 8 \mathrm{~cm} \text { (solid) } \\
\text { Left: } 6.5 \mathrm{~cm} \text { (solid) }\end{array}$ & 125 & $\begin{array}{l}\text { Surgical debulking, } \\
\text { chemotherapy with } \\
\text { BEP }\end{array}$ & $\begin{array}{l}\text { Succumbed at } \\
18 \text { months }\end{array}$ \\
\hline 5 & Solomovitz et al (9) & 11 & $\begin{array}{l}\text { Right: } 12 \mathrm{~cm} \\
\text { (solid/cystic) }\end{array}$ & 88.5 & $\begin{array}{l}\text { Surgical debulking, } \\
\text { P6 and myeloablative } \\
\text { chemotherapy }\end{array}$ & $\begin{array}{l}\text { Succumbed at } \\
11 \text { months }\end{array}$ \\
\hline 6 & Parker et al (10) & 23 & Right: 6.8 cm (solid) & 140 & $\begin{array}{l}\text { Surgical debulking, } \\
\text { platinum and taxol } \\
\text { chemotherapy }\end{array}$ & None \\
\hline 7 & Elhajj et al (6) & 27 & $\begin{array}{l}\text { Right: } 13 \mathrm{~cm} \text {, } \\
\text { Left: } 20 \mathrm{~cm}\end{array}$ & Not done & $\begin{array}{l}\text { Surgical debulking, } \\
\text { delayed chemotherapy } \\
\text { until symptomatic. C/E } \\
\text { then VDC }\end{array}$ & $\begin{array}{l}\text { Succumbed at } \\
42 \text { months }\end{array}$ \\
\hline 8 & Ota et al (4) & 26 & Bilateral (solid) & 745.8 & $\begin{array}{l}\text { Surgical debulking, } \\
\text { P6 chemotherapy }\end{array}$ & $\begin{array}{l}\text { Succumbed at } \\
23 \text { months }\end{array}$ \\
\hline 9 & Ota et al (4) & 19 & Bilateral (solid) & 2,823 & $\begin{array}{l}\text { Surgical debulking, } \\
\text { BEP }\end{array}$ & $\begin{array}{l}\text { Succumbed at } \\
11 \text { months }\end{array}$ \\
\hline 10 & Fang et al (7) & 13 & Left: $10 \mathrm{~cm}$ & Not done & $\begin{array}{l}\text { Surgical debulking } \\
\text { BEP, radiotherapy }\end{array}$ & $\begin{array}{l}\text { Succumbed at } \\
21 \text { months }\end{array}$ \\
\hline 11 & Fang et al (7) & 23 & $\begin{array}{l}\text { Right: } 11 \mathrm{~cm} \\
\text { Left: } 9 \mathrm{~cm}\end{array}$ & 51.7 & $\begin{array}{l}\text { Surgical debulking, } \\
\text { myeloablative } \\
\text { chemotherapy }\end{array}$ & $\begin{array}{l}\text { Alive at } \\
7 \text { months }\end{array}$ \\
\hline 12 & Engohan-Aloghe et al (8) & 21 & $\begin{array}{l}\text { Right: } 18 \text { cm (solid) } \\
\text { Left: unclear (solid) }\end{array}$ & Not done & $\begin{array}{l}\text { Surgical debulking, } \\
\text { unknown chemotherapy }\end{array}$ & $\begin{array}{l}\text { Alive at } \\
7 \text { months }\end{array}$ \\
\hline 13 & Nakayama et al (3) & 6 & Bilateral (solid) & Not done & $\begin{array}{l}\text { Surgical debulking, P6 } \\
\text { chemotherapy }\end{array}$ & $\begin{array}{l}\text { Succumbed at } \\
28 \text { months }\end{array}$ \\
\hline 14 & Nakayama et al (3) & 28 & $\begin{array}{l}\text { Right: } 10 \mathrm{~cm} \\
\text { (solid/cystic) }\end{array}$ & 42 & $\begin{array}{l}\text { Neoadjuvant IE/VDC } \\
\text { chemotherapy, } \\
\text { debulking surgery }\end{array}$ & $\begin{array}{l}\text { Succumbed at } \\
40 \text { months }\end{array}$ \\
\hline 15 & Nakayama et al (3) & 17 & $\begin{array}{l}\text { Right: } 15 \mathrm{~cm} \\
\text { (multicystic) }\end{array}$ & 35.9 & $\begin{array}{l}\text { Surgical debulking, } \\
\text { IE/VDC chemotherapy } \\
\text { with interval debulking } \\
\text { followed by radiation } \\
\text { therapy }\end{array}$ & $\begin{array}{l}\text { Alive at } \\
11 \text { months }\end{array}$ \\
\hline 16 & Present case & 30 & $\begin{array}{l}\text { Right: } 6.5 \mathrm{~cm} \\
\text { (soild/cystic) }\end{array}$ & 50.8 & $\begin{array}{l}\text { Surgical debulking, } \\
\text { VAC chemotherapy }\end{array}$ & $\begin{array}{l}\text { Alive at } \\
15 \text { months }\end{array}$ \\
\hline
\end{tabular}

DSRCT, desmoplastic small round cell tumors; CA-125, carbohydrate antigen-125; BEP, bleomycin, etoposide and cisplatin; C/E, cisplatin/etoposide; VDC/VAC, vincristine, adriamycin, and cyclophosphamide; I/E: ifosfamide/etoposide.

majority of patients undergo chemotherapy following surgery, the prognosis has been shown to be independent of whether the surgical debulking process preceded or followed chemotherapy. The overall progression-free 5-year survival rate of
DSCRT patients is $18 \%$. The aggressive nature of the disease and the low overall survival rates achieved should be carefully explained to affected patients and their families, who should be included in the decision-making process $(2,16,18,21,22)$. 
In conclusion, based on previous studies and the present case, it is known that DSRCT is an uncommon and aggressive tumor that affects adolescents, particularly young men. The majority of patients are in the late stages of the disease upon presentation. Currently, a combination of surgery and chemotherapy are commonly used for treatment; however, it is difficult to confirm whether surgery before or after chemotherapy is most effective in such patients. Taken together, analysis of the reported 15 cases and the present case, it appears that following surgery with or without chemotherapy all the patients entered at least partial remission; however, tumor recurrence and metastases occurred in a number of cases. This may be due to the proliferative nature and the divergent differentiation of the tumor cells, which resulted in the cells losing sensitivity to the chemotherapy.

\section{Acknowledgements}

This study was supported by the National Natural Science Foundation of China (grant no. 81101992).

\section{References}

1. Gerald WL and Rosai J: Case 2. Desmoplastic small cell tumor with divergent differentiation. Pediatr Pathol 9: 177-183, 1989.

2. Zaloudek C, Miller TR and Stern JL: Desmoplastic small cell tumor of the ovary: A unique polyphenotypic tumor with an unfavorable prognosis. Int J Gynecol Pathol 14: 260-265, 1995.

3. Nakayama J, Nassau S, Atkins K and Modesitt SC: Desmoplastic small round cell tumor of the ovary: A rare but devastating disease in young women. Gynecol Oncol Case Rep 7: 16-18, 2013.

4. Ota S,Ushijima K, Fujiyoshi N,Fujimoto T, Hayashi R, MurakamiF, Komai K, Fujiyoshi K, Hori D, Kamura T: Desmoplastic smal round cell tumor in the ovary: Report of two cases and literature review. J Obstet Gynaecol Res 36: 430-434. 2010.

5. Young RH, Eichhorn JH, Dickersin GR and Scully RE: Ovarian involvement by the intra-abdominal desmoplastic small round cell tumor with divergent differentiation: A report of three cases. Hum Pathol 23: 454-464. 1992.

6. Elhajj M, Mazurka J and Daya D: Desmoplastic small round cell tumor presenting in the ovaries: Report of a case and review of the literature. Int J Gynecol Cancer 12: 760-763. 2002.

7. Fang X, Rodabaugh K, Penetrante R, Wong M, Wagner T, Sait S and Mhawech-Fauceglia P: Desmoplastic small round cell tumor (DSRCT) with ovarian involvement in 2 young women. Appl Immunohistochem Mol Morphol 16: 94-99. 2008.

8. Engohan-Aloghe C, Aubain Sommerhausen Nde S and Noël JC: Ovarian involvement by desmoplastic small round cell tumor with leydig cell hyperplasia showing an unusual immunophenotype (cytokeratin negative, calretinin and inhibin positive) mimicking poorly differentiated sertoli leydig cell tumor. Int Gynecol Pathol 28: 579-583. 2009.
9. Slomovitz BM, Girotra M, Aledo A, Saqi A, Soslow RA, Spigland NA and Caputo TA: Desmoplastic small round cell tumor with primary ovarian involvement: case report and review. Gynecol Oncol 79: 124-128, 2000.

10. Parker LP, Duong JL, Wharton JT, Malpica A, Silva EG and Deavers MT: Desmoplastic small round cell tumor: Report of a case presenting as a primary ovarian neoplasm. Eur J Gynaecol Oncol 23: 199-202, 2002.

11. Backer A, Mount SL, Zarka MA, Trask CE, Allen EF, Gerald WL, Sanders DA, Weaver DL: Desmoplastic small round cell tumour of unknown primary origin with lymph node and lung metastases:histological, cytological, ultrastructural, cytogenetic and molecular findings. Virchows Arch 432: 135-141, 1998

12. Gerald WL, Miller HK, Battifora H, Miettinen M, Silva EG and Rosai J: Intra-abdominal desmoplastic small round-cell tumor. Report of 19 cases of a distinctive type of high-grade polyphenotypic malignancy affecting young individuals. Am J Surg Pathol 15: 499-513, 1991.

13. Layfield LJ and Lenarsky C: Desmoplastic small cell tumors of the pertoneum coexpressing mesenchymal and epithelial markers. Am J Clin Pathol 96: 536-543, 1991.

14. Norton J, Monaghan P and Carter RL: Intra-abdominal desmoplastic small cell tumour with divergent differentiation. Histopathology 19: 560-562, 1991.

15. Ordóñez NG, el-Naggar AK, Ro JY, Silva EG and Mackay B: Intra-abdominal desmoplastic small cell tumor: A light microscopic, immunocytochemical, ultrastructural and flow cytometric study. Hum Pathol 24: 850-865, 1993.

16. Kushner BH, LaQuaglia MP, Wollner N, Meyers PA, Lindsley KL, Ghavimi F, Merchant TE, Boulad F, Cheung NK, Bonilla MA, et al: Desmoplastic small round-cell tumor: Prolonged progression-free survival with aggressive multimodality therapy. J Clin Oncol 14: 1526-1531, 1996.

17. Robboy SJ, Anderson MC and Russel P (eds): Miscellaneous Primary Tumors, The Peritoneum, Pathology of the Female Reproductive Tract. Churchill Livingstone, London, pp 809-810, 2002.

18. Churg A, Cagle PT and Roggli VL (eds): Tumors of the serosal membranes. In: Atlas of Tumor Pathology, 4th series. Armed Forces Institute of Pathology, Washington DC, 122-124, 2006.

19. Ordóñez NG: Desmoplastic small round cell tumor. II: An ultrastructural and immunohistochemical study with emphasis on new immunohistochemical markers. Am J Surg Pathol 22: 1314-1327, 1998.

20. Church DN, Bailey J, Hughes J and Williams CJ: Desmoplastic small round cell tumour: obstetric and gynecological presentations. Gynecol. Gynecol Oncol 102: 583-586, 2006.

21. Slomovitz BM, Girotra M, Aledo A, Saqi A, Soslow RA, Spigland NA and Caputo TA: Desmoplastic small round cell tumor with primary ovarian involvement: Case report and review. Gynecol Oncol 79: 124-128, 2000.

22. Schwarz RE, Gerald WL, Kushner BH, Coit DG, Brennan MF and La Quaglia MP: Desmoplastic small round cell tumors: Prognostic indicators and results of surgical management. Ann Surg Oncol 5: 416-422, 1998. 